\title{
Safety of Growth Hormone Treatment
}

\section{Feyza Darendeliler}

Istanbul University, Istanbul Faculty of Medicine, Department of Pediatrics, Pediatric Endocrinology Unit, Istanbul, Turkey

Keywords:
growth hormone, adverse
effect, safety
Received: 16 June, 2008
Accepted: 9 October, 2008
Corresponding Author:
Feyza Darendeliler
Istanbul University, Istanbul
Faculty of Medicine,
Department of Pediatrics
Pediatric Endocrinology Unit,
Istanbul, Turkey
E-mail:
feyzad@istanbul.edu.tr

Keywords: effect, safety

Received: 16 June, 2008 Corresponding Author: Faculty of Medicine, feyzad@istanbul.edu.tr

\section{ABSTRACT}

Growth hormone $(\mathrm{GH})$ is being used in the treatment of GH deficiency and in the treatment of other conditions with increasing frequency. Several uncommon potentially adverse events including idiopathic intracranial hypertension (IIH), slipped capital femoral epiphysis (SCFE), increase in the number of pigmented nevi, gynecomastia, scoliosis, insulin resistance and a possible increase in malignancy have been associated with $\mathrm{GH}$ treatment. Despite its potential adverse effects, GH has had a good safety record up to now. This review will focus on the potential side effects of GH treatment in $\mathrm{GH}$ and non-GH deficient conditions.

Conflict of interest: None declared

\section{INTRODUCTION}

There has been a dramatic increase in the use of exogenous growth hormone $(\mathrm{GH})$ for treatment since biosynthetic recombinant human GH (rhGH) became available in 1985. At present, besides GH deficiency, children with a wide variety of growth disorders are receiving $\mathrm{GH}$ treatment. Supraphysiological doses of $\mathrm{GH}$ are being used in non-GH deficient growth disorders.(1) Moreover, the action of $\mathrm{GH}$ via its receptor involves many organ systems and metabolic pathways and for this reason, the safety of $\mathrm{GH}$ treatment has become a major concern of issue in recent years. The aim of this paper is to review the potential side effects of GH treatment in different disorders treated with GH.

\section{SODIUM AND WATER RETENTION}

Side effects of GH treatment like periphSUPPLEMENT seen in adulthood are rarely encountered in childhood.(2) Fluid retention and carpal tunnel syndrome are rare in children.

\section{IDIOPATHIC INTRACRANIAL HYPERTENSION}

Idiopathic intracranial hypertension (IIH) is defined as intracranial hypertension in the absence of a space occupying lesion and is characterized by increased cerebrospinal fluid (CSF) pressure with normal CSF composition, bilateral papilledema, visual changes, headache, nausea and vomiting. The incidence in childhood is $1 / 100.000$.(3) $\mathrm{IIH}$ has been reported following $\mathrm{GH}$ treatment not only in patients with GH deficiency, but also in chronic renal insufficiency (CRI), Prader Willi syndrome (PWS) and Turner syndrome (TS).(4, 5, 6) The pathogenesis of IIH occurring with GH treatment may be due to its effects on body fluid distribution 
and resultant changes in fluid balance. Alternatively or in addition, GH may cross the blood brain barrier and increase local levels of insulin like growth factor-I (IGF-I) which in turn increases CSF production from the choroid plexus.(2) Large pharmacoepidemiological surveys have revealed an increase in IIH upon GH treatment $(6,7,8)$ and reported frequencies ranging from 81 to $120 / 100,000$. It is likely to occur in patients with CRI, TS, organic GH deficiency and PWS.(7) IIH has been associated with some medications (L-thyroxine, glucocorticoid, vitamin A and D) as well as with obesity, anemia, uremia and female gender. The onset of IIH is generally seen within a short period time ( 2-12 weeks) after start of GH therapy, but it may also be seen months later. The signs and symptoms of IIH usually disappear and clinical improvement may occur within weeks or months after discontinuation of GH therapy. Symptoms usually do not reappear after reinitiating $\mathrm{GH}$ in low doses, probably due to homeostatic adjustment.(9) Loss of visual acuity or visual fields is a serious permanent complication of IIH.

\section{ORTHOPEDIC PROBLEMS}

Slipped capital femoral epiphysis (SCFE) is a disorder of the femoral head growth plate leading to a displacement of the femoral head epiphysis from its normal alignment. The incidence ranges from 2 to 13/100,000 individuals between 7 and 17 years of age.(10, 11) It may be associated with obesity, trauma, rapid growth, endocrine disturbances including hypothyroidism, hypogonadism and $\mathrm{GH}$ deficiency.(12) In GH deficiency, the growth plates are wide and this may result in weakness even without GH treatment. GH contributes to the widening of the weakest zone of the epiphyseal plate and thus may increase the risk of SCFE in GH deficient children treated with GH.(13) Pain in the hip or knee and limp are the major symptoms of SCFE and Xray of the hip is the best diagnostic tool.
Treatment consists of correcting the displacement of the epiphysis with continuation of $\mathrm{GH}$ therapy recommended after orthopedic evaluation.(14)

The incidence of SCFE on GH treatment in pharmacoepidemiological surveys and national databases varies between 4 to 272 $/ 100,000$ and is higher than the incidence in the general population. $(7,15,16,17,18,19)$ However, it is difficult to assess the risk of SCFE in the general population because it varies with age, sex, race, geographical location and season. GH deficiency itself may cause SCFE and there may be other risk factors such as obesity, delayed skeletal maturation or other hormone deficiencies. Children with organic GH deficiency, TS and CRI are more prone to SCFE.(7) Obesity is a risk factor in these diagnostic groups.

The incidence of Perthe's disease on GH treatment which may occur in GH deficient children independently of GH therapy does not seem to be increased on GH treatment compared to the general population $(\sim 5-7)$ 100,000).(2)

Idiopathic scoliosis is most often seen in early adolescence and is more frequent in girls. Scoliosis is seen in $\sim 4 \%$ of healthy school children. The frequency of scoliosis on GH treatment does not seem to be increased, $(20,21)$ but progression of scoliosis may be rapid.(2, 20) Some diagnostic groups like TS and PWS are prone to scoliosis. $(17,21,22)$ It is increased during any period of rapid linear growth and is not independently correlated with GH therapy.(17, 20) Follow up is needed in risk groups.

\section{CARBOHYDRATE METABOLISM}

There has been a concern for the potential for induction of glucose intolerance or type 2 diabetes regarding GH treatment especially in children with disorders such as TS, CRI and low birth weight (children born small for gestation age-SGA). All of these disorders are known to be associated with abnormalities in carbohydrate metabolism. GH acts as an 
insulin antagonist. Nearly all studies of GH therapy in children show an increase in insulin levels but normal glucose tolerance.(23, 24) One pharmacoepidemiological study demonstrated an increased frequency of type 2 diabetes in children receiving GH approximately six-fold higher than previously reported incidence figures.(25) However, other long term databases have been reassuring. $(24,26,27,28)$ A large multicenter GHpostmarketing surveillance study reported diabetes or impaired glucose tolerance in approximately $1 \%$ of $\mathrm{GH}$ treated patients with CRI.(18) SGA born short children show insulin resistance on $\mathrm{GH}$ treatment which resolves after discontinuation of GH therapy.(29) Although published data form large postmarketing databases for $\mathrm{GH}$ treated children born SGA do not report adverse events, (5, 17, 21, 30) more long term follow up of carbohydrate metabolism is needed in these groups of children.(31) The long term consequences for prolonged hyperinsulinemia remain unclear.

\section{MALIGNANCY}

GH has been shown to increase the risk of malignancy in in vitro and animal studies(32) and it may increase the risk of cancer in humans. $(33,34)$ Thus, another concern has been the malignant transformation on $\mathrm{GH}$ treatment. In initial reports, increased incidence of leukemia in $\mathrm{GH}$ recipients has been reported.(35, 36) However, careful evaluation of national and multinational databases has not shown a significant increase in the risk of leukemia associated with GH therapy unless risk factors such as cytotoxic chemotherapy, genetic or hematological conditions or radiotherapy are present. $(5,18,37,38)$ Relapse of leukemia has not been increased in database analyses. $(5,36,37,38,39,40,41)$ There is no increase in risk of developing a new extracranial nonleukemic neoplasm in $\mathrm{GH}$ recipients either.(42, 43) Regarding tumor recurrences in GH treated patients with brain tumors, data from single and multicenter studies(39, 44, 45, 46, 47, 48, 49, 50) have shown no increased risk of tumor recurrence. Risk of second neoplasm in survivors of childhood cancer treated with GH analyzed in a report from the Childhood Cancer Survivor Study (CCSS) group, has revealed a small but significant increased risk of developing secondary neoplasm but the numbers are small and the elevation of risk due to $\mathrm{GH}$ use appears to diminish with increasing length of follow up(51); therefore continuing surveillance is mandatory. $(52,53,54,55,56,57,58,59,60)$ A higher than expected incidence of and mortality from colonic cancer and Hodgkin's disease has been reported in GH deficiency treated with hGH.(61) However, the relatively small cohort and small number of cases argue for caution. Furthermore in the old days hGH was given twice or three times weekly which probably resulted in unphysiological high IGF-I levels. Available data in international databases do not support for excess malignancy in children treated with GH.(62) There is no evidence of an increase in the incidence of de novo intracranial tumours in childhood.(49)

\section{ENDOCRINE PROBLEMS}

GH therapy does not cause a significant change in thyroid function. However, thyroid function should be evaluated prior to initiating therapy in GH deficiency.(63) GH can modulate the activity of the enzyme $11 \beta$ hydroxysteroid dehydrogenase type 1 which is responsible for the conversion of cortisone to cortisol and prednisone to prednisolone. An increase in $\mathrm{GH}$ leads to a reduction in cortisol production.(64) This interaction needs to be considered in patients receiving glucocorticoid replacement therapy.

\section{OTHER UNDESIRABLE EFFECTS}

Although in vitro and in vivo studies have shown that GH and IGF-I affect numerous immune functions, (65) these abnormalities do not appear to be reflected in the clinical findings. Reports of anti GH antibodies in patients receiving $\mathrm{GH}$ have been few with 
no adverse net result on growth response.

The potential adverse effect of $\mathrm{GH}$ on the number and size of nevi has been controversial but recent studies show no such effect.(66)

There is no increase in seizures on $\mathrm{GH}$ therapy.(2)

With respect to gonadal axis, there is no adverse affect on spermatogenesis, testicular volume and morphology in animal studies(67) and in databases of $\mathrm{GH}$ use in humans.(21) Gynoecomastia has been reported as an adverse event with an incidence of 0.32/1000.(68) GH does not seem to have an effect on pubertal timing.(2) Although initial reports have stated that $\mathrm{GH}$ may accelerate bone age maturation, (69) this effect has remained as a controversial issue for years. However, it has been shown in some studies that when used in supraphysiological doses GH may accelerate bone age in idiopathic short stature (ISS).(70)

Acute pancreatitis is another possible rare complication of $\mathrm{GH}$ therapy.

\section{POTENTIAL ADVERSE EFFECTS IN SPECIFIC DIAGNOSTIC GROUPS}

There is no deterioration of renal function in patients with CRI on GH treatment.(71) An increase in the rate of graft rejection in $\mathrm{GH}$ treated children has been reported especially in those with a history of previous rejection episodes.(72) However, GH is used with success in children with CRI after renal transplantation. Careful monitoring of renal function is mandatory in patients after renal transplantation. Available data do not consistently show a significant risk for renal carcinoma in CRI after renal transplantation,(73) but in such patients routine ultrasound should be done to facilitate early tumor detection.

There is no increase in the frequency of otitis media in TS patients receiving GH.(74) Recent analysis of side effects in TS in a large pharmacoepidemiological survey(22) has revealed that it is very important to identify the risk factors in the natural history of the disease to be able to evaluate the potential adverse events. In this study, the incidence of certain events known to be associated with $\mathrm{GH}$, including IIH, SCFE, scoliosis and pancreatitis, were increased compared to other nonTS cases in the survey. Type 1 diabetes was also increased. The aortic dissection/rupture incidence, the authors concluded, reflects the higher baseline risk for these events in TS. The ratio for de novo malignancies in the TS cohort seems to be increased compared to the rate in the general population although statistical significance was lacking.

The reported adverse events during GH treatment in patients with PWS are similar to those observed in other diagnostic groups. Low insulin levels prior to $\mathrm{GH}$ therapy increase during GH treatment. Glucose levels remain unchanged.(75) However, close follow up is mandatory.(76) Some children with PWS suffer from respiratory disturbances with chronic hypoventilation. There have been some reports of sudden death in patients with PWS upon GH therapy.(77) However the causality is still not clear. Furthermore GH therapy has a beneficial effect on ventilation and respiratory functions.(78, 79) However, prior to GH treatment patients with PWS should undergo polysomnography and tonsillectomy may be performed if needed. Children with upper respiratory tract infections should be monitored for sleep apnea. $(79,80)$

In conclusion, the use of rhGH has a good safety record. However, some disorders that are already prone to certain complications such as TS, PWS and SGA should be carefully monitored for certain side effects.

\section{REFERENCES}

1. Quigley CA. Growth hormone treatment of non-growth hormone-deficient growth disorders. Endocrinol Metab Clin N Am 2007;36:131-186. [Full Text / PDF] 
2. Clayton $P E$, Cowell $C T$. Safety issues in children and adolescents during growth hormone therapya review. Growth Hormone \& IGF Research 2000;10:306-317. [Abstract / PDF]

3. Babikian $\mathrm{P}$, Corbett J, Bell W. Idiopathic intracranial hypertension in children: the lowa experience. J Child Neurol 1994;9:144-149. [Abstract / PDF]

4. Price DA, Clayton PE, Lloyd IC. Benign intracranial hypertension induced by growth hormone treatment. Lancet 1995;345:458-459.

5. Blethen SL, Allen DB, Graves D, August G, Moshang T, Rosenfeld R. Safety of recombinant deoxyribonucleic acid-derived growth hormone; the National Cooperative Growth Study experience. J Clin Endocrinol Metab 1996;81:1704-1710. [Abstract / PDF]

6. Crock PA, McKenzie JD, Nicoll AM, Howard NJ, Cutfield W, Shield LK, Byrne G. Benign intracranial hypertension and recombinant growth hormone therapy in Australia and New Zealand. Acta Paediatr 1998;87:381-386. [Abstract]

7. Darendeliler F, Karagiannis G, Wilton P. Headache, idiopathic intracranial hypertension and slipped capital femoral epiphysis during growth hormone treatment: a safety update from the KIGS database. Horm Res 2007;68(suppl 5):41-47. [Abstract / Full Text / PDF]

8. Reeves GD, Doyle DA. Growth hormone treatment and pseudotumor cerebri: coincidence or close relationship? J Pediatr Endocrinol Metab 2002;15(suppl.2):723-730. [Abstract]

9. Malozowski S, Tanner LA, Wysowski DK, Fleming GA, Stadel BV. Benign intracranial hypertension in children with growth hormone deficiency treated with growth hormone. J Pediatr 1995;126:996-999. [Abstract]

10. Henrikson B. The incidence of slipped capital femoral epiphysis. Acta Orthop Scand 1969;40:365372. [Full Text]

11. Kelsey JL, Keggi KJ, Southwick WO. The incidence and distribution of slipped capital femoral epiphysis in Connecticut and Southwestern United States. J Bone Joint Surg 1970;52:1203-1216. [Abstract / PDF]

12. Loder RT, Wittenberg B, DeSilva G. Slipped capital femoral epiphysis associated with endocrine disorders. J Pediatr Orthop 1995;15:349-356. [Abstract]

13. Harris WR. The endocrine basis for slipping of the upper femoral epiphysis. An experimental study. J Bone Joint Surg 1950;32B:5-11. [PDF]

14. Wilson TA, Rose SR, Cohen P, Rogol AD, Backeljauw P, Brown R, Hardin DS, Kemp SF, Lawson M, Radovick S, Rosenthal SM, Silverman L, Speiser P. Update of guidelines for the use of growth hormone in children: the Lawson Wilkins Pediatric Endocrinology Society Drug and Therapeutics Committee. J Pediatr 2003;143:415-421. [Full Text / PDF]

15. Rappaport EB, Fife D. Slipped capital femoral epiphysis in growth hormone-deficient patients. Am J Dis Child 1985;139:396-399. [Abstract]

16. Job JC, Maillard F, Goujard J. Epidemiologic survey of patients treated with growth hormone in France in the period 1959-1990. Horm Res 1992;38:35-43. [Abstract / Full Text]

17. Cowell CT, Dietsch S. Adverse events during growth hormone therapy. J Pediatr Endorinol Metab 1995;8:243-252. [Abstract]

18. Maneatis T, Baptista J, Connelly K, Blethen S. Growth hormone safety update from the National Cooperative Growth Study. J Pediatr Endocrinol Metab 2000;13 (Suppl 2):1035-1044. [Abstract]

19. Blethen SL, Rundle AC. Slipped capital femoral epiphysis in children treated with growth hormone. A summary of the National Cooperative Growth Study Experience. Horm Res 1996;46:113-116. [Abstract / Full Text]

20. Wang ED, Drummond DS, Dormans JP, Moshang T, Davidson RS, Gruccio D. Scoliosis in patients treated with growth hormone. J Pediatr Orthoped 1997;17:708-711. [Abstract / Full Text]

21. Wilton P. Adverse events reported in KIGS. In: Growth Hormone Therapy in Pediatrics: 20 years of KIGS. Eds. Ranke MB, Price DA, Reiter EO. Karger Basel 2007; 432-441.

22. Bolar K, Hoffman AR, Maneatis T, Lippe B. Long-term safety of recombinant human growth hormone in Turner Sendrome. J Clin Endocrinol Metab 2008;93:344-351. [Abstract / Full Text / PDF]

23. Hokken-Koelega AC, Stijnen T, de Jong RC, Donckerwolcke RA, Groothoff JW, Wolff ED, Blum WF, de Muinck Keizer-Schrama SM, Drop SL. A placebo-controlled, double-blind trial of growth hormone treatment in prepubertal children after renal transplant. Kidney Int Suppl. 1996;53:S128-134. [Abstract] 
24. Saenger P, Attie KM, DiMartino-Nardi J, Fine RN. Carbohydrate metabolism in children receiving growth hormone for 5 years. Chronic renal insufficiency compared with growth hormone deficiency, Turner syndrome, and idiopathic short stature. Genentech Collaborative Group. Pediatr Nephrol 1996;10:261-263. [Abstract]

25. Cutfield WS, Wilton P, Bennmarker $H$, Albertsson-Wikland $K$, Chatelain P, Ranke MB, Price DA. Incidence of diabetes mellitus and impaired glucose tolerance in children and adolescents receiving growth-hormone treatment. Lancet 2000;355:610-613. [Abstract]

26. Wilson DM, Frane JW, Sherman B, Johanson AJ, Hintz RL, Rosenfeld RG. Carbohydrate and lipid metabolism in Turner syndrome: effect of therapy with growth hormone, oxandrolone, and a combination of both. J Pediatr 1988:112:210-217. [Abstract / PDF]

27. Weise M, James D, Leitner CH, Hartmann KK, Böhles HJ, Attanasio A. Glucose metabolism in Ullrich Turner syndrome: long-term effects of therapy with human growth hormone. German Lilly UTS Study Group. Horm Res 1993;39:36-41. [Abstract]

28. Sas TCJ, de Muinck Keizer-Schrama SM, Stijnen T, Aanstoot HJ, Drop SL. Carbohydrate metabolism during long-term growth hormone $(\mathrm{GH})$ treatment and after discontinuation of $\mathrm{GH}$ treatment in girls with Turner syndrome participating in a randomized dose-response study. Dutch Advisory Group on Growth Hormone. J Clin Endocrinol Metab 2000;85:769-775. [Abstract / Full Text / PDF]

29. van Pareren $Y$, Mulder $P$, Houdijk M, Jansen $M$, Reeser $M$, Hokken-Koelega $A$. Effect of discontinuation of growth hormone treatment on risk factors for cardiovascular disease in adolescents born small for gestational age. J Clin Endocrinol Metab 2003;88:347-353. [Abstract / Full Text / PDF]

30. Cutfield WS, Lindberg A, Rapaport R, Wajnrajch MP, Saenger P. Safety of growth hormone treatment in children born small for gestational age: the US trial and KIGS analysis. Horm Res 2006;65(suppl 3):153-159. [Abstract / Full Text / PDF]

31. Clayton PE, Cianfarani S, Czernichow P, Johannsson G, Rapaport R, Rogol A. Consensus Statement: management of the child born small for gestational age through to adulthood: a consensus statement of the international societies of pediatric endocrinology and the Growth Hormone Research Society. J Clin Endocrinol Metab 2007;92:804-810. [Abstract / Full Text / PDF]

32. Zadik Z, Estrov Z, Karov Y, Hahn T, Barak Y. The effect of growth hormone and IGF-I on clonogenic growth of hematopoietic cells in leukemic patients during active disease and during remission- a preliminary report. J Pediatr Endocrinol 1993;6:79-83. [Abstract]

33. Chan JM, Stampfer MJ, Giovannucci E, Gann PH, Ma J, Wilkinson P, Hennekens CH, Pollak M. Plasma insulin-like growth factor $-\mathrm{I}$ and prostate cancer risk: a prospective study. Science 1998;279:563-566. [Abstract / Full Text / PDF]

34. Hankinson SE, Willett WC, Colditz GA, Hunter DJ, Michaud DS, Deroo B, Rosner B, Speizer FE, Pollak M. Circulating concentrations of insulin-like growth factor I and risk of breast cancer. Lancet 1998;351:1393-1396. [Abstract / Full Text]

35. Watanabe S, Mizuno S, Tsunematsu Y, Komiyama A, Yamanaka C, Kubota M. Leukemia in GHdeficient children. Clin Pediatr Endocrinol 1994;3(suppl 5):53-60.

36. Fradkin JE, Mills JL, Schonberger LB, Wysowski DK, Thomson R, Durako SJ, Robison LL. Risk of leukemia after treatment with pituitary growth hormone. J Am Med Ass 1993;270:2829-2832. [Abstract]

37. Allen DB, Rundle AC, Graves DA, Blethen SL. Risk of leukemia in children treated with human growth hormone: Review and reanalysis. J Pediatr 1997;131(suppl):S32-S36. [Abstract / Full Text / PDF]

38. Nishi Y, Tanaka T, Takano K, Fujieda K, Igarashi Y, Hanew K, Hirano T, Yokoya S, Tachibana K, Saito $\mathrm{T}$, Watanabe S. Recent status in the occurrence of leukemia in growth hormone-treated patients in Japan. J Clin Endocrinol Metab 1999;84:1961- 1965. [Abstract / Full Text / PDF]

39. Ogilvy-Stuart AL, Ryder WD, Gattamaneni HR, Clayton PE, Shalet SM. Growth hormone and tumour recurrence. BMJ 1992;304:1601-1605. [Abstract]

40. Wilton P. Safety of growth hormone value of a large database. Clin Pediatr Endocrino/ 1994;3(suppl 5):61-71.

41. Leiper A. Growth hormone deficiency in children treated for leukemia. Acta Paediatr 1995;84(suppl 411):41-44. 
42. Tuffli GA, Johanson A, Rundle AC, Allen DB. Lack of increased risk for extracranial, nonleukemic neoplasms in recipients of recombinant deoxyribonucleic acid growth hormone. J Clin Endocrinol Metab 1995;80: 1416-1422. [Abstract / PDF]

43. Wyatt D. Lessons from the National Cooperative Growth Study. Eur J Endocrinol 2004:151(suppl 1):S55-S59. [Abstract / Full Text]

44. Clayton PE, Shalet SM, Gattamaneni HR, Price DA. Does growth hormone cause relapse of brain tumours? Lancet 1987;1:711-713. [Abstract]

45. Moshang T Jr. Is brain tumor recurrence increased following growth hormone treatment? Trends Endocrinol Metab 1995;6:205-209.

46. Swerdlow AJ, Reddingius RE, Higgins CD, Spoudeas HA, Phipps K, Qiao Z, Ryder WDJ, Brada M, Hayward RD, Brook CGD, Hindmarsh PC, Shalet SM. Growth hormone treatment of children with brain tumors and risk of tumor recurrence. J Clin Endocrinol Metab 2000;85:4444-4449. [Abstract / Full Text / PDF]

47. Packer RJ, Boyett JM, Janss AJ, Stavrou T, Kun L, Wisoff J, Russo C, Geyer R, Phillips P, Kieran M, Greenberg M, Goldman S, Hyder D, Heideman R, Jones-Wallace D, August GP, Smith SH, Moshang T. Growth hormone replacement therapy in children with medulloblastoma; use and effect on tumor control. J Clin Oncol 2001; 19:480-487. [Abstract]

48. Sklar CA, Mertens AC, Mitby P, Occhiogrosso G, Qin J, Heller G, Yasui Y, Robison LL. Risk of disease recurrence and second neoplasms in survivors of childhood cancer treated with growth hormone: a report from the childhood cancer survivor study. J Clin Endocrinol Metab 2002;87:31363141. [Abstract / Full Text / PDF]

49. Moshang T Jr, Rundle AC, Graves DA, Nickas J, Johanson A, Meadows A. Brain tumor recurrence in children treated with growth hormone: the National Cooperative Growth Study experience. J Pediatr 1996;128(suppl):S4-S7. [Abstract / Full Text / PDF]

50. Darendeliler F, Karagiannis G, Wilton P, Ranke BM, Albertsson-Wikland K, Price DA \& on behalf of the KIGS international board. Recurrence of brain tumours in patients treated with growth hormone: Analysis of KIGS (Pfizer International Growth Database). Acta Paediatr 2006;95:1284-1290. [Abstract]

51. Ergun-Longmire B, Mertens AC, Mitby P, Qin J, Heller G, Shi W, Yasui Y, Robison LL, Sklar CA. Growth hormone treatment and risk of second neoplasms in the childhood cancer survivor. J Clin Endocrino/ Metab 2006;91:3494-3498. [Abstract / Full Text / PDF]

52. Bowlby DA, Rapaport R. Safety and efficacy of Growth Hormone Therapy in childhood. Pediatr Endocrinol Rev 2004;2(suppl 1):68-77. [Abstract]

53. Banerjee I, Clayton PE. Growth hormone treatment and cancer risk. Endocrinol Metab Clin N Am 2007;36:247-263. [Full Text / PDF]

54. Consensus. Critical evaluation of the safety of recombinant human growth hormone administration: statement from the growth hormone research society. J Clin Endocrinol Metab 2001;86:1868-1870. [Full Text / PDF]

55. Harris M, Hofman PL, Cutfield WS. Growth hormone treatment in children. Pediatr Drugs 2004;6:93-106. [Abstract / Full Text / PDF]

56. Lanes R. Long-term outcome of growth hormone therapy in children and adolescents. Treat Endocrinol 2004;3:53-66. [Abstract / Full Text]

57. GH Research Society. Consensus guidelines for the diagnosis and treatment of growth hormone $(\mathrm{GH})$ deficiency in childhood and adolescence: summary statement of the GH research society. J Clin Endocrinol Metab 2000;85:3990-3993. [Full Text / PDF]

58. Hindmarsh PC, Dattani MT. Use of growth hormone in children. Nature Clinical Practice Endocrinology\&Metabolism 2006;2:260-268. [Abstract]

59. Saggese G, Ranke MB, Saenger P, Rosenfeld RG, Tanaka T, Chaussain JL, Savage MO. Diagnosis and treatment of growth hormone deficiency in children and adolescents: Towards a Consensus. Horm Res 1998;50:320-340. [Abstract]

60. Meacham LR, Sullivan K. Characteristics of growth hormone therapy for pediatric patients with brain tumors in the National Cooperative Growth Study (NCGS) and from a survey of pediatric endocrinologists. J Pediatr Endocrinol Metab 2002; 15(suppl 2):689-696. [Abstract] 
61. Swerdlow AJ, Higgins CD, Adlard P, Preece MA. Risk of cancer in patients treated with human pituitary growth hormone in the UK, 1959-1985: a cohort study. Lancet 2002;360:273-277. [Abstract]

62. Sperling MA, Saenger PH, Hintz R, Wilson T, Rose SR; Lawson Wilkins Pediatric Endocrine Society. LWPES Executive Committee and the LWPES Drug and Therapeutics Committee. Special editorial: growth hormone treatment and neoplasia - coincidence or consequence? J Clin Endocrinol Metab 2002;87:5351-5352. [Full Text / PDF]

63. Municchi G, Malozowski S, Nisula BC, Cristiano A, Rose SR. Nocturnal thyrotropin surge in growth hormone-deficient children. J Pediatr 1992;121:214-220. [Abstract]

64. Moore JS, Monson JP, Kaltsas G, Putignano P, Wood PJ, Sheppard MC, Besser GM, Taylor NF, Stewart PM. Modulation of $11 \mathrm{~B}$-hydroxysteroid dehydrogenase isozymes by growth hormone and insulin-like growth factor: in vivo and in vitro studies. J Clin Endocrinol Metab 1999;84:4172-4177. [Abstract / Full Text / PDF]

65. Auernhammer CJ, Strasburger CJ. Effects of growth hormone and insulin-like growth factor I on the immune system. Eur J Endocrinol 1995;133:635-645. [Abstract]

66. Zvulunov A, Wyatt DT, Laud PW, Esterly NB. Lack of effect of growth hormone therapy on the count and density of melanocytic naevi in children. Br J Dermato/ 2006;137:545-548. [Abstract / PDF]

67. Sjögren I, Ekvärn S, Zühlke U, Vogel F, Bee W, Weinbauer GF, Nieschlag E. Lack of effects of recombinant human $\mathrm{GH}$ on spermatogenesis in the adult cynomolgus monkey (Macaca Fascicularis). Eur $J$ Endocrinol 1999;140:350-357. [Abstract]

68. Wilton P. Adverse events during GH treatment: 10 years' experience in KIGS, a Pharmacoepidemiological Survey. In: Ranke MB, Wilton P, (eds). Progress in Growth Hormone Therapy-I0 years of KIGS. Ja Barh Verlag 1999; 349-364.

69. Darendeliler F, Hindmarsh PC, Preece MA, Cox L, Brook CGD. Growth hormone increases rate of pubertal maturation. Acta Endocrinol (Copenh) 1990,122:414-416. [Abstract]

70. Kamp GA, Waelkens JJJ, de Muinck Keizer-Schrama SMPF, Delemarre-Van de Waal HA, VerhoevenWind L, Zwinderman AH, Wit JM. High dose growth hormone treatment induces acceleration of skeletal maturation and an earlier onset of puberty in children with idiopathic short stature. Arch Dis Child 2002;87:215-220. [Abstract / Full Text / PDF]

71. Fine RN, Ho M, Tejani A, Blethen S. Adverse events with rhGH treatment of patients with chronic renal insufficiency and end-stage renal disease. J Pediatr 2003;142:539-545. [Abstract / Full Text / PDF]

72. Guest G, Bérard E, Crosnier H, Chevallier T, Rappaport R, Broyer M. Effects of growth hormone in short children after renal transplantation. French Society of Pediatric Nephrology. Pediatr Nephrol 1998;12:437-446. [Abstract]

73. Mehls O, Wilton P, Lilien M, Berg U, Broyer M, Rizzoni G, Waldherr R, Opelz G. Does growth hormone treatment affect the risk of post-transplant renal cancer? Pediatr Nephrol 2002;17:984-989. [Abstract]

74. Roush J, Quigley CA, Bryant CG, et al. Effect of GH treatment on ear disease in young girls with Turner syndrome (TS) (abstract 902). Presented at the annual meeting of the Lawson Wilkins Pediatric Endocrine Society and Pediatric Academic Societies. San Francisco, May 1-4, 2004.

75. Burman P, Ritzen EM, Lindgren AC. Endocrine dysfunction in Prader-Willi syndrome: a review with special reference to GH. Endocr Rev 2001;22:787-799. [Abstract]

76. Lindgren AC, Hagenas L, Ritzen EM. Growth hormone treatment of children with Prader-Willi syndrome: effects on glucose and insulin hemeostasis. Swedish National Growth Hormone Advisory Group. Horm Res 1999;51:157-161. [Abstract]

77. Eiholzer U, Nordmann Y, I'Allemand D. Fatal outcome of sleep apnoea in PWS during the initial phase of growth hormone treatment. Horm Res 2002;58(Suppl 3): 24-26. [Abstract]

78. Lindgren AC, Hellström LG, Ritzen EM, Milerad J. Growth hormone treatment increases $\mathrm{CO}_{2}$, response, ventilation and central inspiratory drive in children with Prader-Willi syndrome. Eur J Pediatr 1999;158:936-940. [Abstract]

79. Festen DA, de Weerd AW, van den Bossche RAS, Joosten K, Hoeve H, Hokken-Koelega ACS. Sleeprelated breathing disorders in prepubertal children with Prader - Willi syndrome and effects of growth hormone treatment. J Clin Endocrinol Metab 2006; 91:4911-4915. [Abstract / Full Text / PDF]

80. Miller J, Silverstein J, Shuster J, Driscoll DJ, Wagner M. Short -term effects of growth hormone on sleep abnormalities in Prader-Willi syndrome. J Clin Endocrinol Metab 2006;91:413-417. [Full Text / PDF] 